\title{
Nations and Numbers: Elementary Mathematics Education as a Nationalizing Tool
}

\author{
Lukas Boser
}

University of Applied Sciences and Arts, Institute of Primary Education

\section{Abstract}

One of the central elements of the nation-building process in the 19th century was the attempt to homogenize the citizenry, i.e. to fabricate national citizens. Besides the military and church, schools were considered to be the main agencies capable of achieving this national homogenization. In this paper, focusing on the education in Switzerland and France, I argue that elementary mathematics education was also used for this particular purpose. I make the case that throughout the 19th century mathematics education became a way to familiarize the people with a standardized language - a language that was supposed to help them master their specific social, cultural and political realities.

Key words: mathematics education; nation building; Standard Language Ideology; state formation.

\section{Introduction}

"The battle in which the Swiss cut the army of Charles the Bold, Duke of Burgundy, to pieces in front of Murten took place in 1476. How many years passed from that time until 1827?" (Voruz, 1826, p. 15). This is one of 100 arithmetical problems presented in an elementary school textbook published by the Swiss teacher Amédée Voruz (1797-1871) in 1826 . From a mathematical point of view, this problem can be solved by performing a simple subtraction: 1827 minus 1476 equals 351 . However, there is much more to such problems than simple arithmetic. My argument is loosely based on a question formulated a few years ago by Valero and Pais (2015), "What if school mathematics is not important in society due to the exceptional and intrinsic characteristics of the academic field that gives this school subject its name" but because of other aspects? (p. 177). By posing this question, Valero and Pais make the point that mathematics 
education in school is not limited to "the teaching and learning of ... neutral practices" (p. 177). Mathematics education, therefore, is as much about numbers and calculations as it is about social, cultural, and political configurations. In particular, I argue in this paper that, throughout recent history, elementary mathematics education was involved in creating images of cultural and mental homogeneity within both a particular nation (i.e. the Swiss nation) and a particular nation state (i.e. France).

I have chosen Switzerland and France as examples, for France is often seen as a typical 19th-century nation state, which means that the French nation converges with the actual French state, whereas Switzerland is an interesting case because the Swiss nation is a complex compound of sovereign states, i.e. the cantons. Even after a Swiss federal state was founded in 1848, the cantonal autonomy remained strong, which makes it difficult to this day to think of Switzerland as a nation state. Even though nations and nation states have often been seen as natural entities, they are not (see Tröhler, 2020a). Nations are made up by people, they are culturally construed "imagined communities" - to use a well-known concept introduced by Benedict Anderson (1983). This imagined concept is conveyed and consolidated by symbols, labels, flags and signs (Billig, 1995), as well as by practices (Renan, 1882). In order to create a stable image of what a nation was, people had to be taught to recognize and to understand the symbols, labels, flags and signs that marked the existence of the nation. Or in the words of Tröhler (2020a, 2020b), a "national literacy" had to be spread among the populace. At the same time, national ways of doing things had to be identified (and in some cases invented) and standardized among the people. In many 19th- and 20th-century countries, teachers and pedagogues attempted to standardize handwriting in elementary education in order to create a common practice that reflected national homogeneity (e.g. Boser \& Hofmann, 2019; Caruso, 2019), and similar attempts were made with elementary mathematics education.

To underscore the argument that elementary mathematics education was deliberately used to infuse young people with a national image and to establish a national literacy, it is worthwhile to take a closer look at the statement made by Voruz quoted earlier. Voruz was a teacher in a canton called Vaud which had been under Savoy rule until it was annexed in part in 1476 and in full in 1536 by the then sovereign member states of the Old Swiss Confederacy Bern and Fribourg. Owing to this change of power, Vaud was included into the Swiss Confederacy, albeit not as a sovereign member state but as a subject territory. Only in 1803 Napoleon Bonaparte granted Vaud its independency as a sovereign state, whereby it joined the Swiss Confederacy on equal terms. Obviously, the Vaud region had an eventful history to which Voruz could have referred. Instead, he chose "the Swiss" and "1476" in order to illustrate his arithmetical problem, and, as I argue, he had a particular reason to do so. When Voruz published his textbook in 1826, Vaud was a sovereign state, equipped with its own school system for which Voruz's book was intended. Yet, the 1820s were also a time when national sentiments grew in the Swiss cantons. "Historical thinking played a continuing part in political 
movements" (Church \& Head, 2013, p. 147), and in schools (Dahn \& Boser, 2015). It is exactly this "historical thinking" that Voruz's arithmetical problem aimed to trigger. "The Swiss" he was referring to had not been the citizens of Switzerland, for such a state did not exist in 1476 - or in 1826 for that matter. Switzerland, and therefore "the Swiss," were nothing but an "imagined community" until 1848. In order to strengthen this notion of "Switzerland" and "the Swiss," Voruz referred to their century-long proud tradition of fighting against foreign enemies.

This Invention of Tradition argument (Hobsbawm \& Ranger, 1983) is supported by another arithmetical problem that is to be found in Voruz's textbook. It reads as follows: "The Battle of Morgarten, in which the Confederates cut the Austrian army commanded by Leopold to pieces, was fought in 1313. Seventy-three years later came the Battle of Sempach, in which Arnold of Winkelried devoted himself to his country; and two years later the people of Glarus, with the help of their brothers from Schwyz, completely defeated the Austrian nobility at Näfels. In which years did the battle of Sempach and the battle of Näfels take place?" (Voruz, 1826, p. 14).

Technically, to Voruz's students, those events happened not only in a time long past but also in foreign countries. Not one of the battles mentioned in Voruz's arithmetical problems had anything to do with their own state's past or present. In the introduction to his textbook, Voruz wrote that he wanted his students to be able to solve "ordinarylife" problems (p. II). In what way, however, were battles - fought by foreigners a very long time ago - part of the students' ordinary lives? Here again, my argument is that in introducing them, Voruz's intent was to evoke national imagination. Although the battles as such had nothing to do with the students' ordinary lives, as central elements to an emerging national myth, they gave answers to highly pertinent questions such as: Who are we as a Swiss nation? What makes us Swiss a nation? How did we become a Swiss nation? In short, the Battles of Morgarten, Sempach, Näfels and Murten were part of a national myth, a national sentiment, or - to use Renan's (1882) words they were elements of a spiritual principle which constituted the soul of the nation. This spiritual principle lay the foundation for a national identity and, in this regard, the battles mentioned in Voruz's arithmetical problems indeed became part of the students' ordinary lives.

But I am getting ahead of myself. Before coming back to 19th-century national sentiments and the role elementary mathematics education played in their evocation, in the following section, I will discuss arithmetic education in the Ancien Regime. In the next, the third section, I will then present two concepts of mathematics education developed by the French Marquis de Condorcet (1743-1794) and the Swiss Johann Heinrich Pestalozzi (1746-1827), respectively. In the fourth section, using the examples of France and Switzerland, I will outline the role elementary mathematics education played in nation building and in nation-state building processes in the 19th century. Here, I will also introduce a concept that was originally developed in sociolinguistics, the concept of the Standard Language Ideology. In the concluding section, I will once 
again lay out my argument that elementary mathematics education was a nationalizing tool in 19th-century France and Switzerland.

The source material I am drawing on in this work consists mainly of arithmetic textbooks. As a result of this deliberate choice, my sources cover only a part of mathematics education while ignoring, for instance, geometry or algebra. This is due to the fact that my research is limited to elementary education, where mathematics education is almost entirely focused on arithmetic. Furthermore, I am drawing on the large body of research published in the last decades in the field of history of education in general, and the field of history of mathematics education in particular. I will focus on a very broad timespan, beginning in the 16th century and ending in the 19th, with a strong focus on the latter. Geographically, I will focus on what is today's France and Switzerland, but I will also take a peek at Austria and Germany.

\section{Arithmetic education in the Ancien Regime}

For centuries, men and women living in Europe had to possess some basic arithmetic knowledge. Merchants needed to keep track of their income and expenditure, housewives had to know how much money they could spend, astronomers and astrologers calculated the movements of celestial objects, clerks had to collect taxes, clergymen had to list births and deaths, and peasants reckoned the size of their haystacks, to give only a few examples. Most of these skills and knowledge were not taught and learned in schools, but were rather acquired with the help of a private tutor, through lessons given by parents or a master, by working in a shop, or by shopping and selling at local farmers' markets. However, by the end of the Middle Ages, some professions, especially in commercial towns, began to establish schools where students were taught to read, write and calculate. "For merchants, ... writing and arithmetic have been part of their professional knowledge since the High Middle Ages, and this knowledge was increasingly taught in ... writing and arithmetic schools" (Wunder, 2015, p. 48). Some of those schools were run by local authorities, others were privately run, such as the school advertised in the city of Basel in 1516. We know of this school because a signboard, painted by famous artists Hans and Ambrosius Holbein, has withstood the test of time and is now on display at the Art Museum in Basel. On this signboard, a teacher offers his services. The text on the signboard explains that those services in particular consisted of teaching how to keep track of one's debts. Because the original wording says that people will be taught to "note" and "read" their debts (sin schuld uff schribe und läsen), historians often assume that this school mainly focused on reading and writing skills (e.g. Wunder, 2015). I think, however, that in this school teaching was mainly about bookkeeping and therefore also about arithmetic, for bookkeeping does not make sense without arithmetic.

Schools like the one in Basel flourished almost exclusively in towns or larger marketplaces; however, mathematical knowledge and skills were not evenly distributed among the people. Instead, the level of mathematical instruction (and thus knowledge) depended 
on one's profession and social status (Wunder, 2015). With regard to mathematics education in the city of Weimar, Klinger (2014) points to the correlation between the students' social status and mathematics education they received. Different social groups had their own schools where children were taught different mathematics curricula.

In rural villages, as mathematics education was scarce, peasants usually taught their children the kind of arithmetic people living in countryside needed to know. A school survey conducted in 1770/71 in the rural areas of the canton of Zurich gives a good insight into rural schooling in the Early Modern period (Tröhler \& Schwab, 2006). Using the survey findings, Rosenmund (2006) concluded that "although a majority of the children was proficient in reading by the end of school, only a minority achieved writing skills and the number of those who learn arithmetic was even much smaller" (p. 52). The few children who were taught mathematics in school "typically included almost only the male offspring of rich farmers or craftsmen" (p. 52). A survey conducted in the Helvetic Republic in 1799 reveals that, in the canton of Vaud, even rural schools usually offered arithmetic education. The survey, however, does not provide any details on the characteristics of children that were taught arithmetic. In the city of Lausanne, for instance, where Amédeé Voruz later taught, only one out of four elementary schools for girls offered arithmetic education, but all of the boys' schools did. In the city's orphanage, however, boys were taught "fundamentals" of arithmetic, which indicates that orphan boys received much less mathematics education than the bourgeoisie's male offspring (Schmidt et al., 2015).

This means that mathematics education in early modern Europe varied considerably. As Valero and Pais (2015) aptly surmised, in early modern Europe "each field of practice that we can call 'mathematical' has particular rules of use and exists in its particular form as shaped by the people who are part of such a practice" (p. 176). Consequently, those practices shaped the people who exercised them. This certainly holds true for members of different professions and different social strata within early modern society. However, it also holds true in a more general sense. If we keep our focus on social configurations, we find that social stratification was not only symbolized but also reinforced and perpetuated by different forms of mathematics education.

However, by the end of what we call the Early Modern Period in Europe, a new notion of mathematics education emerged. It was during the time of the Austrian empress Maria Theresa's regency (1740-1780) when "education became emphatically a matter of political concern, a politicum ... as the empress famously explained in a decree in 1770" (Viehhauser, 2019, p. 20). By order of the empress, the Silesian Abbot Johann Ignaz von Felbiger (1724-1788) developed a uniform, mandatory elementary school system for the German-speaking part of Austria. As Viehhauser argues, this new concept of schooling was indeed part of a state formation process. Schooling was standardized and made compulsory "in order to integrate the state's population" into the monarchy (p. 20). In this process of integrating people into a state - which itself 
developed into a modern administrative state - mathematics played an important role. While vernacular languages remained unaffected by Felbiger's attempts to standardize schooling, mathematics - which was the language of modern political science and statistics - was made uniform throughout the empire."The preoccupation with surveys and overviews, abstract numbers, and charts of the territories shaped a conceptual scheme of what a 'state' was' (Viehhauser, 2019, p. 22), and mathematics education provided the population with the skills needed to understand this conceptual scheme.

\section{Mathematics as a universal language: Condorcet and Pestalozzi}

A few years after Felbiger's death, the French Marquis de Condorcet advanced the idea of teaching everyone the same mathematics by promoting the notion that mathematics was a universal language that could and should be spoken by everyone. The nobleman Condorcet was a well-known mathematician, the secretary of the Académie des Sciences in Paris, a protagonist of the (early) French Revolution, the coauthor of the (ultimately unsuccessful) Girondin constitutional project in 1793, the author of a project aimed at reforming the French educational system, and an advocate of universal suffrage and women's rights (Boser, 2020). Today Condorcet is well known as one of the masterminds of late Enlightenment, and is famed for his book Esquisse d'un tableau historique des progrès de l'esprit humain (Outlines of a Historical View of the Progress of the Human Mind), written in 1793, among his many noteworthy accomplishments. However, at the same time as Condorcet wrote the Esquisse, he also produced a small textbook for elementary mathematics education (Condorcet, 1800). The two books are in fact interrelated (Boser, 2020). While the Esquisse contains the theory about the progress of the human mind, the arithmetic textbook is the key to facilitating this progress. In the Esquisse, Condorcet explained that humanity stood at the verge of the final stage of progress. Yet, to enable humankind to take the last step everybody had to learn a particular universal language. The language Condorcet had in mind, however, was not a modern language, such as French or English, nor was it a classical language, such as Latin or Greek. What he was thinking of was mathematics.

The notion of a universal language was not truly original at that time. For example, the value of such a language had been pointed out by the German philosopher Gottfried Wilhelm Leibniz (1646-1716) almost a century before Condorcet formulated his thoughts on that matter (Kulstad \& Carlin, 2013). What makes Condorcet's notion of a universal language particularly interesting for the purpose of the present analysis is that he had found such a language in mathematics. In Condorcet's understanding, mathematics was universal in so far as its basic elements and rules always stayed the same no matter the cultural or linguistic context. More importantly, mathematics was the language in which nature revealed itself. In other words, Condorcet took the term "universal language" literally, for he opined that it is the language of the universe itself, and is therefore also the language of nature and every natural thing, law or event. 
According to Condorcet, understanding this natural language was the most important step and means towards greater perfection of humankind (Tröhler, 2014). It was therefore essential for the evolution of mankind that everybody learned this language in school. Hence, his elementary school textbook is nothing less than a profound introduction to this language.

In one respect only, Condorcet's mathematics education remained arbitrary - the numeral system. Any number could serve as a base for a numeral system, whether two, ten or twelve, as none seemed more "natural" than the other. Condorcet's friend, the encyclopedist Jean Baptiste D'Alembert (1717-1783), for instance, praised the binary system for being particularly concise and simple (D'Alembert, 1751). As a base two numeral system, binary system requires only two symbols, such as 0 and 1 commonly used today. Owing to this simplicity and the ease with which presence of something (1) and its absence (0) can be distinguished, it has found many applications in technology. Indeed, most modern computers are based on the binary system. However, its major disadvantage is that even small numbers tend to become very long when written in binary form (the binary equivalent to the decimal number 100, for instance, has more than twice as many digits - 1100100). For people who did their computations with ink and quill, the length of the numbers was certainly an issue, which is probably why Condorcet chose the decimal system for his elementary mathematics course. From today's perspective, this may look like an obvious choice; however, we have to keep in mind that for most everyday calculations at the time the duodecimal or the hexadecimal system would have been more suitable, for they allow a much easier handling of common fractions (e.g. 1/3, 1/4, 1/6). When Condorcet and others chose to standardize elementary school mathematics by adopting the decimal system, they forced upon the people a way of thinking that poorly fit their customs and everyday needs. This fact notwithstanding, mathematicians and textbook authors in the late 18th and early 19th century persisted with the decimal system and forced their students to use it too.

Another man whose work was decisive for the advancement of the decimal system in elementary schools, albeit for completely different reasons, was Johann Heinrich Pestalozzi, who developed a new course for mathematics education at the turn of the century. Actually, Pestalozzi had major help from his friends, but the new "method" he promoted became famous under his name - the Pestalozzi Method (Waridel, 2003). In 1803, Pestalozzi published a multi-volume arithmetic book (Pestalozzi, 1803a, $1803 \mathrm{~b}, 1803 \mathrm{c}, 1803 \mathrm{~d}$ ). The mathematics presented in this book focused on numbers, lines and squares. Pestalozzi's students were not supposed to learn how to solve everyday problems, but rather to master the abstract rules of mathematics as such. Like Condorcet's book, Pestalozzi's mathematics course was also entirely decimalized. Pestalozzi was convinced that the key to understanding the "substantial order of the world" (Osterwalder, 2008, p. 31) was to be found in this decimalized, abstract mathematics education. Because Pestalozzi wanted every child to see the godly order 
in the world, every child had to be taught his particular kind of mathematics. The main difference between Condorcet and Pestalozzi was that for Condorcet mathematics was a universal language of nature, whereas for Pestalozzi it was a language that reflected the divine order in nature (Osterwalder, 2008).

Although for different reasons, both Condorcet and Pestalozzi wanted every child to learn the same mathematics. Abstract mathematics, such as that promoted by Condorcet or Pestalozzi, was not bound to a group of people, a social class, a state, or even a nation. Rather, it was meant to be truly universal. However, although their work was widely recognized - and in the case of Pestalozzi's method highly praised their concepts of an abstract mathematics education did not last. People did not want their children to learn a new language or to see God's order in the world but to solve what was called "everyday problems." Joseph Schmid (1785-1851), one of Pestalozzi's friends that helped him to develop his method, wrote about Pestalozzi's students: "They cannot calculate the things going on in the domestic sphere" (Schmid, 1810, p. III). This was a particularly serious accusation because most of Pestalozzi's students were sons of merchants who were supposed to learn the skills needed in their future businesses (Schmid, 1810).

\section{The language of the (nation-)state: Cases of France and Switzerland}

In the 19th century, mathematics was taught neither as a universal language nor as an expression of God's order in the world, but as a nationalizing or state-forming tool. This is the argument I am going to make in this section. The use of elementary mathematics education as a means for establishing a national literacy can be analyzed by examining 19th-century arithmetic textbooks. Textbooks are particularly informative sources because those published in the 19th century specifically determined the content of the mathematics curriculum. Most of those textbooks were written by teachers, while some were authored by mathematicians or pastors. It is noteworthy that many of those textbook authors knew Pestalozzi's books and some were also familiar with Condorcet's work. Yet, almost all of them were of the opinion that teaching "pure" (i.e. abstract) mathematics only made sense when complemented with what they called "applied mathematics" (Egger, 1858, p. III).

Applied mathematics was meant to focus on real-life, everyday problems. And even though everyday life looked entirely different for boys and girls, for a farmer's offspring, for the children of a craftsman, or for a merchant's family, applied mathematics was supposed to look the same for all of them, at least in elementary school. This can be illustrated by analyzing the content of 19th-century textbooks published in the Swiss cantons. In those books, for the first time, the focus shifted from educating future merchants or members of a particular social class to teaching all Swiss children, which was reflected in the book's titles. Even though every canton had its own school system, with individual school laws and curricula, some textbooks referred to all of 
Switzerland by indicating that those books were "Swiss," i.e. that they were meant to be used in Swiss elementary schools (e.g. Egger, 1858; Schulthess, 1808; Tobler, 1805; Zähringer, 1854). While no such thing as a Swiss elementary school ever existed in the exact sense of the word, the emphasis on the word "Swiss" in the textbooks' titles served several means. First, it expanded the potential market for the textbooks, which was important for their authors, whose profits would substantially increase if their books could be sold in over twenty cantons. Still, the use of the word "Swiss" was motivated by much more than simply financial interests. If a book was dedicated for the use in "Swiss elementary schools," this strengthened the notion of Switzerland being an actual nation.

The shift in the notion of mathematics education from being a tool that mirrored and reinforced social differences to serving a nationally unifying role did not proceed uncontested. Why, people asked, should a city dweller know how to calculate the volume of a haystack? Or why should a peasant know how high a certain mountain is? In the 19th century, teachers, textbook authors and mathematicians offered a variety of answers to those questions, some citing economic necessities and others referring to the notion of mathematics being a tool for enhancing children's mental capacities (Egger, 1858).

From an analytical perspective, I would like to make use of the Standard Language Ideology (SLI) - a concept which helps explain the nation-state formation process in the 19th century. The SLI was developed by sociolinguists in order to analyze the attempt to foster uniformity within a nation state by standardizing the national language (Schoemaker \& Rutten, 2019). A similar concept is also discussed under the term "onenation-one-language" ideology (Blommaert, 1999). In the words of Schoemaker and Rutten (2019), SLI is the "linguistic expression of the wider phenomenon of cultural nationalism" (p. 755). Usually, SLI focuses on spoken and written language and its standardization within nation states such as France, Germany or the Netherlands. However, I argue that mathematics education can also be seen as a part of SLI.

The French school law of 1833, drafted by François Guizot (1787-1874), is a particularly interesting case to look at. Guizot's school law declared the following school subjects mandatory: religious instruction, reading, writing, "the elements of the French language and of calculation", and the legal system of weights and measures (Alix, 2019, p. 150). By teaching every future French citizen the same standard French, the nation state would be homogenized and strengthened. So far, this is pure SLI. However, the Guizot Law also emphasized the importance of mathematics, the French weights and measures in particular. Alix (2019) explains that at "the time, the school subjects [mentioned in the Guizot-Law] were decisive means to unify the nation through teaching French in every commune and by standardizing the various local systems of weights and measures" (p. 152). The plan to turn "peasants into Frenchmen" by teaching them a standardized language is discussed at length by Weber (1976). Weber also shows how heavily contested this concept was, and how long it took to actually establish 
a standard language in France, which, according to him, did not occur until after World War I. Equally arduous was the attempt to standardize weights and measures, although there was no lack of teaching material for that purpose (e.g. A. G.-C., 1843; Baget, 1836; Bentz, 1837; Bergery, 1845). Since the metric weights and measures were fully decimalized, their introduction also supported the standardization of primary mathematics education by underscoring the unique importance and usefulness of the decimal system.

Eventually, a fairly standardized (i.e. decimalized) mathematics, using national currency as well as national weights and measures, was taught in French elementary schools. And although mathematics is not exactly the same as a national language, it is nevertheless an important means of communication, not least in modern societies, where the thinking in quantities started to gain increasing importance (Labaree, 2011). When the textbook author L.-J. George wrote in 1832 that his book contained "everything we need to know for our social relations" (cover page), he was referring exactly to this understanding of mathematics. This notion of mathematics as a means of communication - and a very important one for that matter - is not far from Condorcet's view of mathematics as a universal language. However, while Condorcet was thinking about a universal language, mathematics education in 19th-century France materialized as a "national language," as it was related to the national economy, was based on national weights and measures, and was meant to unify the people within the French nation state.

Similar to France, the idea that communication within the state - or the nation could be standardized by standardizing mathematics grew strong in 19th-century Switzerland. And just as in France, in the case of Switzerland, the process of nationalizing elementary mathematics education was neither smooth nor straightforward. This was not least due to the fact that elementary mathematics in Switzerland had to simultaneously serve as a tool for state formation as well as a means for nation building. If state formation - in the same sense as we can find it in Austria in the 1770s - was the goal, the unification of elementary mathematics education focused on the cantons, because in Switzerland - at least until 1848 - the term "state" referred to the cantons. If nation building was the goal, the unification of elementary mathematics education focused on Switzerland as a whole - just as the above-mentioned arithmetical problems posed by Voruz did, where "Swiss" history and supposedly decisive "Swiss" battles were discussed. Throughout the entire 19th century, periods when mathematics textbooks had a strong national emphasis alternated with periods when elementary mathematics education was strongly oriented towards the cantons (Brühwiler, 2017). As mentioned in the introduction, since statehood in the cantons stayed strong, the idea of a Swiss nation state remained contested.

One example from the 1850s conveys both the state-forming and the nation-building capabilities of elementary mathematics education in Switzerland particularly well. In 1848 , the newly founded federal state introduced standardized weights and measures. 
Nevertheless, most people continued to use the customary weights and measures adopted ages ago. In most textbooks for arithmetic education in elementary schools, in order to stay relevant for the students' everyday lives, those customary weights and measures were retained. In the 1850s, however, prominent textbook authors began to use the national weights and measures instead (Boltshauser, 1852; Hug, 1854; Zähringer, 1854), arguing that enforcing state law was an important task of schools. In this regard, mathematics education was intentionally used to promote the interests of the state. At the same time, the use of nationwide standardized weights and measures in elementary mathematics education, advocated by the same textbook authors, further shifted elementary mathematics in Switzerland towards becoming a national way of dealing with numbers and quantities. Hence, elementary mathematics can also be seen as a tool for extending national literacy.

To summarize, in the 19th century, mathematics education became a means for standardizing the language of modern quantitative thinking in France and Switzerland. Although the many textbooks used in elementary mathematics education in each of these nations were far from congruent, one can nevertheless find such "national languages" in those textbooks. By introducing the decimal system as the one and only numeral system, by promoting standardized weights and measures, by referring to a "national" history, by describing the state's topography, by reminding the students of supposedly typical national produce such as milk, and by illustrating supposedly typical cantonal habits such as wine consumption, textbook authors created a standardized language that was meant to be taught to every member of the state or the nation through mathematics education in elementary schools.

The textbook authors created this nationalized elementary mathematics curriculum not because everybody needed to know how to solve the same mathematical problems but because in the modern world mathematics had become an important "technique for mastering reality" (Weber, 1976, p. 94). Moreover, it became an important technique for shaping and ordering reality (Haas et al., 2019). For people in France, this reality meant living in a nation state, whereas for people in Switzerland it meant being a member of both a nation (Switzerland) and a state (their canton). Accordingly, it is not surprising that France and Switzerland (i.e. the Swiss cantons) developed their own elementary mathematics education that fitted their particular social and political needs and goals. This "nationalized" elementary mathematics education was both a reaction to nationalizing and state-forming processes as well as a - intentionally created and used - tool for expediting those processes.

\section{Conclusion}

The historical phenomenon explored in this paper is that of the transformation of elementary mathematics education over time. Technically, mathematics as a whole consists of an "enormously rich variety of ideas, methods, algorithms, techniques and, if you like, institutions and practices" (Lundin, 2011, as cited in Pais \& Valero, 2012, 
p. 19). Accordingly, in Early Modern times mathematics education consisted of a heterogeneous set of skills and knowledge that was taught differently depending on the students' social status and future profession. However, throughout the 19th century, mathematics in public elementary schools developed into a subject that consisted of a relatively small selection of highly standardized topics aimed at developing skills and knowledge everybody was supposed to master. This standardization of elementary mathematics education in the 19th century took place in the context of state formation and nation building. Because the development of public elementary schooling was closely entangled with those processes, elementary mathematics education also became an integral part of the state-formation and nation-building initiatives. If the authors of textbooks for elementary mathematics education wanted the curriculum to be applicable to the students' real life, it had to keep up with those processes. Schools had to deal with constitutions and laws, as was the case for instance when schools were supposed to strengthen the new constitutional monarchy in France in the 1830s. In some cases, textbook authors even responded proactively to new constitutions or laws. When the Swiss confederacy's constitution of 1848 standardized weights and measures, no law obliged the schools to use them in their textbooks. However, Swiss textbook authors began to use Swiss weights and measures in order to support the state. In this case, elementary mathematics education was meant to familiarize people with something that legally already existed. But the standardization and nationalization of elementary mathematics education were more than just a response to constitutions and laws. As shown in the example of Voruz, elementary mathematics education was also used to evoke the image of a nation, even before a corresponding state or nation state legally existed. In both the responsive and the proactive way of dealing with state-forming and nation-building processes, elementary mathematics education was supposed to familiarize the students with a particular (i.e. "national") way of thinking.

Against this backdrop, I borrowed a concept from sociolinguistics in order to analyze the changes in elementary mathematics education. While I concur with Weber (1976), who stated that "language" is "one technique for mastering reality" (p. 94), I offered a view that mathematics is another technique for achieving the same aim. Still, one could choose to follow Condorcet by saying that mathematics is the most important language for mastering reality. If, for the sake of the argument, we adopt Condorcet's understanding of mathematics as a language, some interesting theoretical approaches open up. In the context of this paper, the research about Standard Language Ideology is particularly interesting, for it shows how the standardization of national languages was a tool for making national citizens in the 18th and 19th century (e.g. Schoemaker \& Rutten, 2017). The argument I put forward in this paper is that mathematics taught in elementary schools was standardized and nationalized in the 19th century with the same intent, which was to impose on the members of a state or nation a specific language that enabled them to deal with social, economic, cultural and political realities.

Moreover, just as the French language is more to the French than just a tool for communication, the mathematics taught in elementary schools became more than 
just a technique for mastering reality. It also became a tool for shaping and ordering reality in a sense that it gave answers to essential questions people living in 19th-century Europe had to deal with, such as the ones already mentioned in the introduction to this paper: Who are we as a nation? What makes us a nation? How did we become a nation?

Finally, elementary mathematics education was a means to impose on the students a particular way of dealing with numbers and quantities. In this regard, through mathematics, the children learned a particular way of thinking. Most importantly, however, was that elementary mathematics education standardized the way of dealing with numbers and quantities - including the way of thinking about numbers and quantities - throughout nations, such as Switzerland, and nation states, such as France. In this regard, the theoretical approach adopted to understand the mathematics taught in elementary mathematics education as a language may also further advance our understanding of how elementary school education fostered a "national literacy" during the 19th and 20th century.

\section{References}

A. G.C. (1843). Une première année d'arithmétique: contenant les définitions préliminaires de cette science, l'exposé du système métrique .... Peltier-Voisin.

Alix, S.A. (2019). Citizens in their right place: Nation building and mass schooling in nineteenth-century France. In J. Westberg, L. Boser, \& I. Brühwiler (Eds.), School Acts and the Rise of Mass Schooling (pp. 145-169). Palgrave Macmillan. https://doi.org/10.1007/9783-030-13570-6 7

Anderson, B. (1983). Imagined communities. Verso.

Baget, J.J. (1836). Leçons élémentaires d'arithmétique raisonnée: à l'usage des écoles primaires, des classes élémentaires et des aspirans aux brevets .... Lecointe.

Bentz, L. (1837). Premiers élémens d'arithmétique: suivis de problèmes raisonnés en forme d'anecdotes, à l'usage de la jeunesse. Delalain.

Bergery, C.-L. (1845). Arithmétique des écoles primaires (8e édition). Mme Thiel.

Billig, M. (1995). Banal nationalism. SAGE.

Blommaert, J.(1999). Language Ideological Debates. De Gruyter. https://doi.org/10.1515/9783110808049

Boltshauser, H. (1852). Beispielsammlung der reinen und angewandten Arithmetik, oder 4000 Uebungsbeispiele aus den verschiedenen Gebieten der reinen und angewandten Arithmetik. H. Blom.

Boser, L. (2020). Life-histories. In D. Tröhler (Ed.), Bloomsbury Cultural Histories of Education. Volume IV: Enlightenment (pp. 169-186). Bloomsbury Publishing.

Boser, L., \& Hofmann, M. (2019). Fraktur or Antiqua in primary schools? The struggle for a unified typeface in Switzerland between the 1860s and the first decades of the 20th century. Paedagogica Historica, 55(6), 792-811. https://doi.org/10.1080/00309230.2019.1653945 
Brühwiler, I. (2017). Contested citizenship: Public schooling and political changes in early nineteenth-century Switzerland. Journal of Educational Media, Memory and Society, 9(2), 15-39. https://doi.org/10.3167/jemms.2017.090202

Caruso, M. (2019). "Letra inglesa": Educators, teachers, and the quest for identity in the Hispanic world (1820-1860). Paedagogica Historica, 55(6), 733-753. https://doi.org/10.1 $\underline{080 / 00309230.2019 .1622575}$

Church, C. H., \& Head, R. C. (2013). A Concise History of Switzerland. Cambridge University Press. https://doi.org/10.1017/CBO9781139013765

Condorcet, M.-J.-A.-N. de Caritat, Marquis de. (1795). Outlines of a historical view of the progress of the human mind. Lang and Ustick.

Condorcet, M.-J.-A.-N. de Caritat, Marquis de. (1800). Moyens d'apprendre a compter surement et avec facilité. Bachelier.

Dahn, N., \& Boser, L. (2015). Learning to see the nation-state - History, geography and public schooling in late 19th century Switzerland. Bildungsgeschichte: International Journal for the Historiography of Education, 5(1), 41-56.

D'Alembert, J. B. (1751). Binaire. In D. Diderot \& J. B. D'Alembert (Eds.), Encyclopédie ou Dictionnaire raisonné des sciences, des arts et des métiers (Vol. 2, pp. 257-258). Le Breton/ Durand/Briasson/Michel-Antoine David. https://doi.org/10.5962/bhl.title.82225

Egger, J. (1858). Methodisch-praktisches Rechenbuch für schweizerische Volksschulen und Seminarien mit circa 6000 Uebungsaufgaben. K. J. Wyss.

George, L.-J. (1832). Arithmétique des écoles primaires. L. Vincenot.

Haas, S., Schneider, M. C., \& Bilo, N. (2019). Die Zählung der Welt. Franz Steiner Verlag.

Hobsbawm, E., \& Ranger, T. (1983). The Invention of Tradition. Cambridge University Press.

Hug, J. C. (1854). Die Mathematik der Volksschule: Ein methodisches Handbuch für einen dem Wesen der Volksschule entsprechenden und alle ihre Stufen umfassenden Unterricht. Friedrich Schulthess.

Klinger, K. (2014). Zwischen Gelehrtenwissen und handwerklicher Praxis: Zum mathematischen Unterricht in Weimar um 1800. Wilhelm Fink. https://doi.org/10.30965/9783846756553

Kulstad, M., \& Carlin, L. (2013). Leibniz's philosophy of mind. In E. N. Zalta (Ed.), Stanford Encyclopedia of Philosophy https://plato.stanford.edu/archives/win2013/entries/leibniz-mind/

Labaree, D. (2011). The lure of statistics for educational researchers. Educational Theory, 61, 621-632. https://doi.org/10.1111/j.1741-5446.2011.00424.x

Osterwalder, F. (2008). Die Methode Pestalozzis - Wahrnehmung, Ordnung und Erlösung. In F. Osterwalder (Ed.), Schriften zur 'Methode' (pp. 7-42). Verlag Pestalozzianum.

Pais, A., \& Valero, P. (2012). Researching research: Mathematics education in the political. Educational Studies, 80(1), 9-24. https://doi.org/10.1007/s10649-012-9399-5

Pestalozzi, J. H. (1803a). Anschauungslehre der Zahlenverhältnisse, Vol. I. Heinrich Gessner.

Pestalozzi, J. H. (1803b). Anschauungslehre der Zahlenverhältnisse, Vol. II. Heinrich Gessner.

Pestalozzi, J. H. (1803c). ABC der Anschauung oder Anschauungs-Lehre der Massverhältnisse, Vol. I. Heinrich Gessner.

Pestalozzi, J. H. (1803d). ABC der Anschauung oder Anschauungs-Lehre der Massverhältnisse, Vol. II. Heinrich Gessner. 
Renan, E. (1882). Qu'est-ce qu'une nation?: Conférence faite à la Sorbonne le 11 mars 1882. Calmann Lévy.

Rosenmund, M. (2006). Volksbildung als Verzichtsleistung: Annäherung an die politische Ökonomie des Zürcher Landschulwesens im 18. Jahrhundert. In D. Tröhler \& A. Schwab (Eds.), Volksschule im 18. Jahrhundert. Die Schulumfrage auf der Zürcher Landschaft in den Jahren 1771/1772 (pp. 51-63). Julius Klinkhardt.

Schmid, J. (1810). Die Anwendung der Zahl auf Raum, Zeit, Werth und Ziffer. Mohr und Zimmer.

Schmidt, H. R., Messerli, A., Osterwalder, F., \& Tröhler, D. (Eds.) (2015). Die Stapfer-Enquête. Edition der helvetischen Schulumfrage von 1799, Nr. 1900. http://www.stapferenquete.ch

Schoemaker, B., \& Rutten, G. (2017). Standard language ideology and Dutch school inspection reports (1801-1854). Sociolinguistica, 31(1), 109-124. https://doi.org/10.1515/soci-2017-0008

Schoemaker, B., \& Rutten, G. (2019). One nation, one spelling, one school: Writing education and the nationalisation of orthography in the Netherlands (1750-1850). Paedagogica Historica, 55(6), 745-771. https://doi.org/10.1080/00309230.2019.1622573

Schulthess, J. (1808). Schweizerische Exempeltafeln für das Zifferrechnen. n.p.

Tobler, J. (1805). Gründlicher Unterricht in der Rechenkunst: Zum Gebrauche der vaterländischen Schweizerjugend und din den Schulen. Jakob Tobler.

Tröhler, D. (2014). Self-reflection, or the intellectual's virtues: The culture-epoch theory as a system of reasoning. In M. Pereyra \& B. Franklin (Eds.), Systems of Reason and the Politics of Schooling. School Reform and Sciences of Education in the Tradition of Thomas S. Popkewitz (pp. 299-318). Routledge.

Tröhler, D. (2020a). Nation-state, education and the fabrication of national-minded citizens (Introduction). Croatian Journal of Education, 21(6), (this (special) issue).

Tröhler, D. (2020b). National literacies, or modern education and the art of fabricating national minds. Journal of Curriculum Studies, 52(5), 620-635. https://doi.org/10.1080/0 $\underline{0220272.2020 .1786727}$

Tröhler, D., \& Schwab, A. (2006). Volksschule im 18. Jahrhundert: Die Schulumfrage auf der Zürcher Landschaft in den Jahren 1771/1772. Julius Klinkhardt.

Valero, P., \& Pais, A. (2015). Examining political perspectives in mathematics education. In C. Bergsten \& B. Sriraman (Eds.), Refractions of mathematics education: Festschrift for Eva Jablonka (pp. 173-196). Information Age Publisher.

Viehauser, M. (2019). „Das Schulwesen aber ist und bleibet allezeit ein politicum“: The Felbiger General School Ordinance and School Reform in the Eighteenth-Century Habsburg Monarchy. In J. Westberg, L. Boser, \& I. Brühwiler (Eds.), School Acts and the Rise of Mass Schooling (pp. 17-40). Palgrave Macmillan. https://doi.org/10.1007/978-3-030-13570-6 2

Voruz, A. (1826). Exercices élémentaires d'arithmétique, suivis d'une méthode générale. Hignou Ainé.

Waridel, F. (2003). Pestalozzi et sa conception de l'arithmétique. Centre de documentation et de recherche Pestalozzi.

Weber, E. (1976). Peasants into Frenchmen: The Modernization of Rural France, 1870-1914. Stanford University Press. 
Wunder, H. (2015). Schule halten in der Frühen Neuzeit: Eine Einführung. In G. Ball \& J. Jacobi (Eds.), Schule und Bildung in Frauenhand. Anna Vorwerk und ihre Vorläuferinnen (pp. 45-75). Harrassowitz Verlag 2015.

Zähringer, H. (1854). Leitfaden für den Unterricht im practischen Rechnen an schweizerischen Volksschulen. Verlags-Comptoir.

\section{Lukas Boser}

Institute of Primary Education

University of Applied Sciences and Arts

Northwestern Switzerland

Obere Sternengasse 7, Postfach 1360,

4502 Solothurn, Switzerland

lukas.boser@fhnw.ch 


\section{Nacije i brojevi: osnovno matematičko obrazovanje kao instrument nacionalizacije}

\section{Sažetak}

Jedan od središnjih elemenata procesa izgradnje nacije u 19. stoljeću bio je pokušaj homogenizacije građanstva, tj. stvaranja nacionalnih građana. Osim vojske i crkve, škole su smatrane glavnim sredstvom u postizanju nacionalne homogenizacije. $U$ ovom radu, koji se fokusira na obrazovanje u Švicarskoj i Francuskoj, tvrdim da je elementarno matematičko obrazovanje također korišteno za ovu posebnu svrhu. Dokazujem da je tijekom 19. stoljeća matematičko obrazovanje postalo način upoznavanja ljudi sa standardiziranim jezikom - jezikom koji im je trebao pomoći pri svladavanju vlastitih specifičnih socijalnih, kulturoloških i političkih stvarnosti.

Ključne riječi: ideologija standardnoga jezika; izgradnja nacije; matematičko obrazovanje; oblikovanje države. 